\title{
KAJIAN PENGARUH ABU BATU KAPUR SEBAGAI PENGGANTI FILLER PADA CAMPURAN HOT ROLLED SHEET WEARING COURSE (HRS-WC)
}

\author{
Jhoniko Melodi ${ }^{1}$, Robby $^{2}$, dan Salonten ${ }^{3}$ \\ ${ }^{123}$ Program Studi Teknik Sipil, Fakultas Teknik, Universitas Palangka Raya \\ E-mail: Jhonikomelodi94@gmail.com, robbykalteng.rk@ rocketmail.com, dan \\ salonten@jts.upr.ac.id/HP.+6285347216186
}

\begin{abstract}
ABSTRAK
Kebutuhan akan material perkerasan jalan, terutama pasir, semakin meningkat seiring dengan banyaknya pembangunan jalan di Kalimantan Tengah. Karena itu perlu adanya material alternatif pasir yang dapat digunakan untuk kebutuhan pembangunan tersebut. Penelitian ini bertujuan untuk mengetahui apakah pasir dan abu batu kapur dari Desa Bawan Kabupaten Pulang Pisau dan dari Kecamatan Kurun Kabupaten Gunung Mas apakah memenuhi persyaratan atau spesifikasi yang telah ditentukan, sehingga dapat digunakan sebagai agregat dalam campuran Hot Rolled Sheet Wearing Course (HRSWC). Perencanaan campuran menggunakan metode Asphalt Institute. Tujuan penelitian ini untuk mengetahui pengaruh penggunaan abu batu kapur sebagai pengganti filler pada campuran Hot Rolled Sheet Wearing Course (HRS-WC). dibuat dua komposisi campuran dengan masing-masing 5 variasi kadar aspal. Komposisi I (tanpa bahan pengganti filler), Komposisi II (menggunakan pengganti filler). Berdasarkan hasil tes Marshall untuk Komposisi I diperoleh nilai Kadar Aspal Optimum (KAO) sebesar 7,35\%, stabilitas 1250 $\mathrm{kg}$, VMA $21 \%$, rongga dalam campuran (VIM) 4,03\%, rongga terisi aspal (VFB) 80,15 $\%$ dan hasil bagi Marshall 390,100 kg/mm. Komposisi II diperoleh nilai Kadar Pengganti Filler Optimum sebesar 7,40\%, stabilitas $1385 \mathrm{~kg}$, VMA 21,15\%, rongga dalam campuran (VIM) 3,90\%, rongga terisi aspal (VFB) 82\% dan hasil bagi Marshall 320,500 $\mathrm{kg} / \mathrm{mm}$.
\end{abstract}

Kata kunci: lapis tipis aspal beton, abu batu kapur, kadar aspal optimum.

\begin{abstract}
The need for road pavement materials, especially sand, is increasing along with the many road constructions in Central Kalimantan. Therefore, there needs to be an alternative material of sand that can be used for the development needs. This study aims to find out if the sand and limestone ash from Bawan Village, Pulang Pisau Regency and from districts Kurun Gunung Mas Regency meet the requirements or specifications that have been determined, so that it can be used as an aggregate in a mixture of Hot Rolled Sheet Wearing Course (HRS-WC). Mixed planning using the Asphalt Institute method.). To find out the effect of using limestone ash instead of fillers on the hot rolled sheet wearing course (HRS-WC) mixture. made two compositions of mixtures with 5 variations of asphalt content each. Composition I (without filler replacement material), Composition II (using filler replacement). Based on marshall test results for Composition I obtained Optimum Asphalt Content (KAO) value of $7.35 \%$, stability of $1250 \mathrm{~kg}$, VMA of $21 \%$, cavity in mixture (VIM) of $4.03 \%$, asphalt filled cavity (VFB) of $80.15 \%$ and yield for Marshall of $390.100 \mathrm{~kg} / \mathrm{mm}$. Composition II obtained optimum filler replacement rate of $7.40 \%$, stability of $1385 \mathrm{~kg}$, VMA of $21.15 \%$, cavity in mixture (VIM) of $3.90 \%$, asphalt filled cavity (VFB) of $82 \%$ and yield for Marshall of $320,500 \mathrm{~kg} / \mathrm{mm}$.
\end{abstract}


Keywords: thin layer of concrete asphalt, limestone ash, optimum asphalt content.

\section{PENDAHULUAN}

Provinsi Kalimantan Tengah merupakan provinsi yang termasuk dalam provinsi terluas di Indonesia. Untuk membangun provinsi Kalimantan Tengah ini supaya dalam pembangunannya merata, pemerintah memprioritaskan infrastruktur pembangunan pada bidang perhubungan dengan membuat prasarana transportasi khususnya jalan, sehingga jalan dapat berfungsi dalam perkembangan pembangunan di suatu daerah.

Kebutuhan akan material perkerasan jalan, terutama batu dan pasir, semakin meningkat seiring dengan banyaknya pembangunan jalan di Kalimantan Tengah, Untuk mengatasi hal tersebut kita dituntut untuk mencari sumber daya material lain, dengan sumber daya yang ada di sekitar. Dengan memanfaatkan bahan material yang tersedia seperti pasir limbah tambang emas masyarakat yang terdapat di sepanjang daerah aliran sungai (DAS) Kahayan, khususnya di Desa Bawan Kabupaten Pulang Pisau, pasir limbah tambang emas tersebut merupakan sedimen hasil buangan tambang emas masyarakat di daerah aliran sungai yang berupa pasir yang muncul ke permukaan air sungai yang mengakibatkan terjadinya pendangkalan daerah aliran sungai yang menimbulkan permasalahan bagi lingkungan di daerah tersebut. Seperti yang kita ketahui pasir sungai sangat bersih dan tidak mengandung filler, karena tercuci oleh derasnya aliran sungai. Oleh karena itu,pasir dari Desa Bawan Kabupaten Pulang Pisau perlu penambahan filler. Salah satu alternatif yang dapat dimanfaatkan adalah batu kapur dari Kecamatan Kurun Kabupaten Gunung Mas sebagai bahan pengisi (Filler).

Kabupaten Gunung Mas dan Kabupaten Pulang Pisau secara umum memiliki daerah pemukiman baik di perkotaan maupun diperdesaan, dengan kondisi jalan banyak yang belum diperkeras menggunakan jenis perkerasan yang sesuai dengan volume lalulintas yang semakin meningkat. Jika digunakan dengan Hot Rolled Sheet-Wearing Course $(H R S-W C)$, sebagai campuran perkerasan jalan di Kabupaten Gunung Mas dan Kabupaten Pulang Pisau, maka dapat dipertimbangkan untuk memanfaatkan abu batu kapur sebagai filler dan pasir lokal sebagai bahan pembentuk utama dan aspal sebagai bahan pengikat.

Natalia (2019) dalam penelitan tugas akhir yang berjudul "Analisis Penggunaan Pasir Limbah Tambang Emas Dari Desa Goha Dan Desa Bawan Kabupaten Pulang Pisau Sebagai Agregat Pada Campuran Hot Rolled Sand Sheet (HRSS)", Berdasarkan hasil tes Marshall untuk Komposisi A diperoleh nilai Kadar Aspal Optimum (KAO) sebesar $7,850 \%$, stabilitas $260 \mathrm{~kg}$, flow 2,889 mm, rongga dalam campuran (VIM) $5 \%$, rongga terisi aspal (VFB) $77 \%$ dan hasil bagi Marshall 88,750 kg/mm. Komposisi B diperoleh nilai Kadar Aspal Optimum (KAO) sebesar 7,774\%, stabilitas $290 \mathrm{~kg}$, flow 2,867 mm, rongga dalam campuran (VIM) 4,714\%, rongga terisi aspal (VFB) $78 \%$ dan hasil bagi Marshall 98,571 kg/mm.

Berdasarkan hasil penelitian tersebut maka perlu untuk meneliti lebih jauh tentang penggunaan Abu Batu Kapur dari Kecamatan Kurun Kabupaten Gunung Mas sebagai bahan pengisi (filler) pada Pasir Limbah Tambang Emas Desa Bawan Kabupaten Pulang Pisau pada campuran Hot Rolled Sheet-Wearing Course (HRS-WC). 


\section{Rumusan Masalah}

Berdasarkan uraian diatas didapatkan rumusan masalah sebagai berikut:

1. Apakah agregat yang digunakan dalam campuran Hot Rolled Sheet Wearing Course (HRS-WC) memenuhi persyaratan spesifikasi.

2. Bagaimana komposisi Hot Rolled Sheet Wearing Course (HRS-WC) yang dihasilkan.

3. Berapa nilai kadar aspal optimum (KAO) dan nilai karakteristik Marshall yang dihasilkan dari nilai kadar aspal optimum (KAO) pada campuran Hot Rolled Sheet Wearing Course (HRS-WC).

4. Berapa nilai karakteristik Marshall yang dihasilkan dengan menggunakan bahan pengisi (filler) Abu Batu Kapur dengan variasi kadar bahan pengganti 6\%, 7\%, $8 \%, 9 \%$ dan $10 \%$ terhadap berat filler yang diperoleh dari berat total agregat.

5. Berapa kadar bahan pengganti optimum dari campuran Hot Rolled Sheet Wearing Course (HRS-WC) dari variasi kadar bahan pengganti yang diteliti.

\section{Tujuan penelitian :}

Tujuan yang diharapkan dari penelitian ini:

1. Mengetahui sifat-sifat fisik agregat yang digunakan dalam campuran Hot Rolled Sheet Wearing Course (HRS-WC).

2. Mengetahui proporsi dari komposisi yang digunakan pada campuran Hot Rolled Sheet Wearing Course (HRS-WC).

3. Menentukan nilai kadar aspal optimum (KAO) serta nilai karakteristik Marshall yang dihasilkan dari nilai kadar aspal optimum (KAO) pada campuran $\mathrm{Hot}$ Rolled Sheet Wearing Course (HRS-WC).

4. Mengetahui nilai karakteristik Marshall yang dihasilkan dengan menggunakan bahan pengisi (filler) Abu Batu Kapur dengan variasi kadar bahan pengganti yang direncanakan.

5. Mengetahui kadar bahan pengganti optimum dari campuran Hot Rolled Sheet Wearing Course (HRS-WC) dari variasi kadar bahan pengganti yang diteliti.

\section{METODE PENELITIAN}

\section{Lokasi dan Objek Penelitian}

Penelitian ini di lokasi Laboratorium Rekayasa Jalan Raya Jurusan Teknik Sipil Fakultas Teknik Universitas Palangka Raya Provinsi Kalimantan Tengah dengan objek penelitian Abu Batu Kapur dari Kecamatan Kurun Kabupaten Gunung Mas sebagai bahan pengisi (filler) pada Pasir Limbah Tambang Emas Desa Bawan Kabupaten Pulang Pisau pada campuran Hot Rolled Sheet-Wearing Course (HRS-WC).

\section{Material}

Material yang digunakan dalam penelitian ini adalah:

1. Abu batu kapur

Abu batu kapur dari Kecamatan Kurun Kabupaten Gunung Mas.

2. Agregat halus

Agregat halus yang digunakan berupa pasir yang berasal dari Desa Bawan dan telah memenuhi persyaratan tes laboratorium.

3. Agregat kasar 
JURNAL KACAPURI

JURNAL KEILMUAN TEKNIK SIPIL

Volume 4 Nomor 2 Edisi Desember 2021

Agregat kasar yang digunakan berupa batu pecah yang berasal. Palu pada stockfile yang berada di Asphalt Mixing Plant (AMP) PT. Kalindra Utama Jalan Trans Kalimantan Palangka Raya-Kuala Kurun Desa Bahu Palawa Kabupaten Pulang Pisau dan telah memenuhi persyaratan tes laboratorium.

4. Aspal yang digunakan sebagai bahan pegikat dalam penelitian ini adalah aspal keras dengan penetrasi 60/70.

\section{HASIL DAN PEMBAHASAN}

\section{Pengujian Sifat-sifat Fisik Agregat}

Pengujian sifat-sifat fisik agregat terdiri dari pengujian gradasi agregat, pengujian berat jenis dan penyerapan agregat, pengujian keausan (abrasi) agregat kasar dan pengujian kadar lempung agregat halus (sand equivalent).

Pemeriksaan gradasi agregat kasar, abu batu dan pasir dilakukan dengan uji analisa saringan yang hasilnya dapat dilihat pada Tabel 1 berikut ini.

Tabel 1. Hasil Analisa Saringan Masing-masing Agregat

\begin{tabular}{|c|c|c|c|c|}
\hline \multirow{2}{*}{ No. Saringan } & \multicolumn{3}{|c|}{ Persentase Lolos Saringan (\%) } & \multirow{2}{*|}{ Eks. Bawan } \\
\cline { 3 - 5 } \multicolumn{2}{|c|}{} & \multicolumn{2}{|c|}{ Eks. Palu } & Pasir (SA) \\
\hline Inch & $\mathrm{mm}$ & Agregat Kasar (CA) & Abu Batu (FA) & 100,00 \\
\hline$\# 3 / 4$ & 19 & 100,00 & 100,00 & 100,00 \\
\hline$\# 1 / 2$ & 12,7 & 76,20 & 100,00 & 100,00 \\
\hline$\# 3 / 8$ & 9,5 & 32,07 & 100,00 & 99,97 \\
\hline No.8 & 2,36 & 6,17 & 83,43 & 86,37 \\
\hline No.30 & 0,60 & 2,72 & 55,53 & 3,00 \\
\hline No.200 & 0,075 & 0,51 & 15,10 & \\
\hline
\end{tabular}

Sumber: Hasil Pemeriksaan (2020)

Pemeriksaan sifat-sifat fisik agregat yang berupa pemeriksaan berat jenis dan penyerapan agregat kasar dan agregat halus, pemeriksaan keausan (Abrasi) agregat kasar dan pemeriksaan kadar lempung (sand equivalent) dapat dilihat pada Tabel 2 berikut ini.

Tabel 2. Hasil Pemeriksaan Sifat Fisik Masing-masing Agregat

\begin{tabular}{|c|c|c|c|}
\hline \multirow{2}{*}{ Pemeriksaan } & \multicolumn{2}{|c|}{ Eks. Palu } & \multirow{2}{*}{ Pasir Bawan } \\
\hline & Agregat Kasar & Abu Batu & \\
\hline Berat Jenis $\left(\mathrm{gram} / \mathrm{cm}^{3}\right)$ & 3,161 & 2,530 & 2,564 \\
\hline $\begin{array}{l}\text { Berat Jenis Kering Permukaan / } \\
\text { SSD }\left(\text { gram } / \mathrm{cm}^{3}\right)\end{array}$ & 3,211 & 2,578 & 2,627 \\
\hline Berat Jenis Semu $\left(\mathrm{gram} / \mathrm{cm}^{3}\right)$ & 3,332 & 2,657 & 2,736 \\
\hline Penyerapan (\%) & 1,570 & 1,903 & 2,460 \\
\hline Keausan / Abrasi (\%) & 23,450 & - & - \\
\hline Sand Equivalent (\%) & - & - & 93,57 \\
\hline
\end{tabular}

Sumber: Hasil Pemeriksaan (2020)

\section{Perencanaan Campuran}

Perencanaan campuran menggunakan metode Asphalt Institute dan perhitungan penggabungan agregat menggunakan cara diagonal. 
JURNAL KACAPURI

JURNAL KEILMUAN TEKNIK SIPIL

Volume 4 Nomor 2 Edisi Desember 2021

Tabel 3. Hasil Perhitungan Gradasi Gabungan Cara Diagonal

\begin{tabular}{|c|c|c|c|c|c|c|c|c|c|}
\hline \multicolumn{2}{|c|}{ No. Saringan } & \multicolumn{2}{|c|}{$\begin{array}{c}\text { Agregat Kasar } \\
\text { (CA) }\end{array}$} & \multicolumn{2}{c|}{ Abu Batu (FA) } & \multicolumn{2}{c|}{ Pasir (SA) } & \multirow{2}{*}{$\begin{array}{c}\text { Total } \\
\text { Kombinasi }\end{array}$} & \multirow{2}{*}{$\begin{array}{c}\text { Spesifikas } \\
\text { i }\end{array}$} \\
\hline inch & $\mathrm{mm}$ & $100 \%$ & $34 \%$ & $100 \%$ & $32 \%$ & $100 \%$ & $34 \%$ & \\
\hline$\# 3 / 4$ & 19,0 & 100,00 & 34,00 & 100,00 & 32,00 & $\begin{array}{c}100,0 \\
0\end{array}$ & 34,00 & 100,00 & 100 \\
\hline$\# 1 / 2$ & 12,7 & 76,20 & 25,91 & 100,00 & 32,00 & $\begin{array}{c}100,0 \\
0\end{array}$ & 34,00 & 91,91 & $90-100$ \\
\hline$\# 3 / 8$ & 9,5 & 32,07 & 10,90 & 100,00 & 32,00 & $\begin{array}{c}100,0 \\
0\end{array}$ & 34,00 & 76,90 & $75-85$ \\
\hline No.8 & 2,36 & 6,17 & 2,10 & 83,43 & 26,70 & 99,97 & 33,99 & 62,78 & $50-72$ \\
\hline No.30 & $\begin{array}{c}0,60 \\
0\end{array}$ & 2,72 & 0,92 & 55,53 & 17,77 & 86,37 & 29,36 & 48,06 & $35-60$ \\
\hline $\begin{array}{c}\text { No.20 } \\
0\end{array}$ & $\begin{array}{c}0,07 \\
5\end{array}$ & 0,51 & 0,17 & 15,10 & 4,83 & 3,00 & 1,02 & 6,03 & $6-10$ \\
\hline
\end{tabular}

Sumber: Hasil Perhitungan (2020)

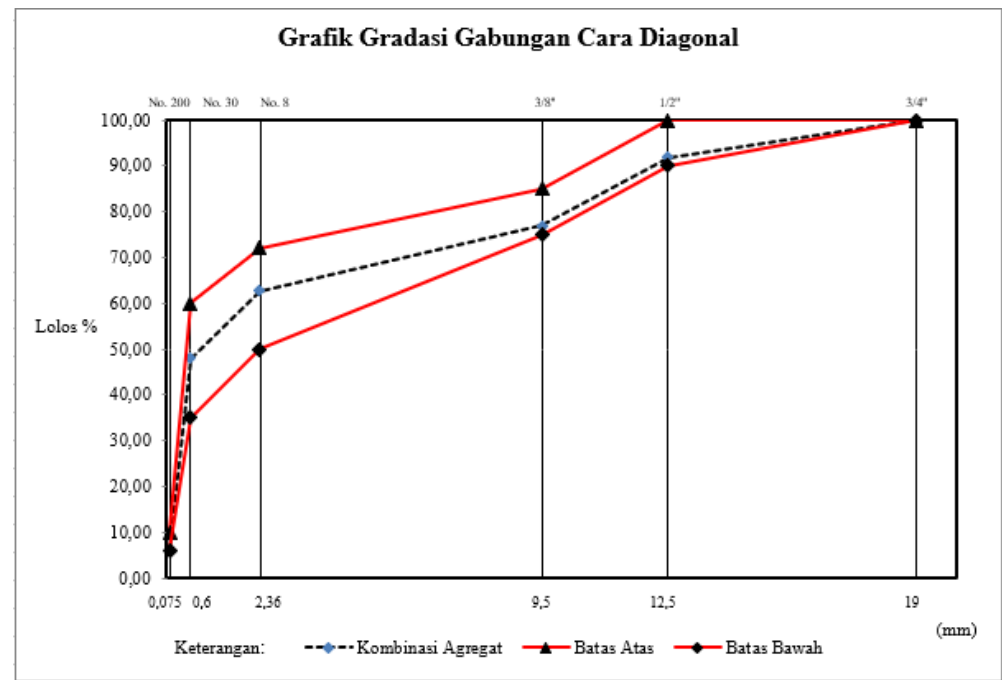

Gambar 1. Grafik Gradasi Gabungan Cara Diagonal

Selanjutnya hasil perhitungan komposisi gradasi agregat gabungan dengan cara diagonal yang sudah diperoleh dikontrol menggunakan cara coba-coba (Trial and Error). Hasil perhitungan untuk proporsi campuran cara coba-coba (Trial and Error) dapat dilihat pada Tabel 4 dibawah ini,

Tabel 4. Hasil Perhitungan Gradasi Gabungan Cara Trial and Error

\begin{tabular}{|c|c|c|c|c|c|c|c|c|c|}
\hline \multicolumn{2}{|c|}{ No. Saringan } & \multicolumn{2}{|c|}{ Agregat Kasar (CA) } & \multicolumn{2}{c|}{ Abu Batu (FA) } & \multicolumn{2}{c|}{ Pasir (SA) } & $\begin{array}{c}\text { Total } \\
\text { Kombinasi }\end{array}$ & \multirow{2}{*}{ Spesifikasi } \\
\cline { 1 - 5 } Inch & $\mathrm{Mm}$ & $100 \%$ & $30 \%$ & $100 \%$ & $34 \%$ & $100 \%$ & $36 \%$ & \\
\hline$\# 3 / 4$ & 19,0 & 100,00 & 30,00 & 100,00 & 34,00 & 100,00 & 36,00 & 100,00 & 100 \\
\hline$\# 1 / 2$ & 12,7 & 76,20 & 22,86 & 100,00 & 34,00 & 100,00 & 36,00 & 92,86 & $90-100$ \\
\hline$\# 3 / 8$ & 9,5 & 32,07 & 9,62 & 100,00 & 34,00 & 100,00 & 36,00 & 79,62 & $75-85$ \\
\hline No.8 & 2,36 & 6,17 & 1,85 & 83,43 & 28,37 & 99,97 & 35,99 & 66,21 & $50-72$ \\
\hline No.30 & 0,600 & 2,72 & 0,82 & 55,53 & 18,88 & 86,37 & 31,09 & 50,79 & $35-60$ \\
\hline No.200 & 0,075 & 0,51 & 0,15 & 15,10 & 5,13 & 3,00 & 1,08 & 6,37 & $6-10$ \\
\hline
\end{tabular}

Sumber: Hasil Perhitungan (2020) 


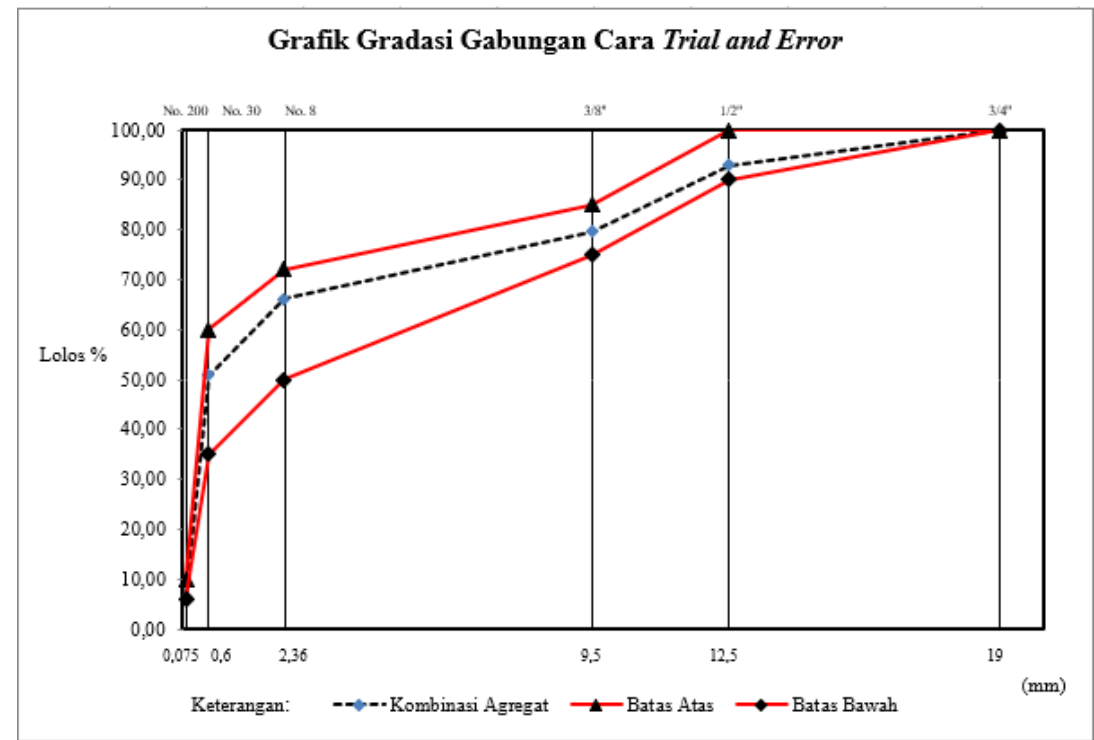

Gambar 2. Grafik Gradasi Gabungan Cara Trial and Error

Hasil perhitungan komposisi campuran berdasarkan cara diagonal dan cara cobacoba (Trial and Error) memenuhi persyaratan gradasi gabungan untuk komposisi campuran Lataston Lapis Aus (HRS-WC) yang direncanakan. Komposisi campuran yang akan digunakan sebagai komposisi untuk pembuatan benda uji adalah hasil perhitungan dari cara coba-coba (Trial and Error) karena nilai total kombinasi cara tersebut lebih mendekati nilai ideal spec.

Dari hasil perhitungan komposisi campuran yang sudah didapat, nilai total kombinasi dapat digunakan untuk menentukan perkiraan kadar aspal awal. Perkiraan kadar aspal awal diperoleh dari rumus berikut, yaitu:

$$
\mathrm{Pb}=0,035(\% \mathrm{CA})+0,045(\% \mathrm{FA})+0,18(\% \text { Filler })+\text { Konstanta }
$$

Keterangan: $\mathrm{Pb} \quad=$ Kadar aspal

$\mathrm{CA} \quad=$ Agregat kasar (Coarse Aggregate)

$\mathrm{FA}=$ Agregat halus (Fine Aggregate)

Filler $\quad=$ Agregat halus lolos saringan No. 200

Konstanta $=2,0-3,0$ (diambil nilai konstanta $=2,0$ )

Hasil perhitungan cara Trial and Error dapat dilihat pada Tabel 4.4 diperoleh agregat yang lolos saringan No. 8 sebesar $66,21 \%$. Untuk nilai CA adalah agregat kasar yang tertahan saringan No. 8 ,

$$
\text { maka nilai } \mathrm{CA}=100 \%-66,21 \%=33,79 \%
$$

Sedangkan untuk nilai FA adalah agregat halus lolos saringan No. 8 dan tertahan saringan No. 200. Maka nilai FA $=100 \%-(\% \mathrm{CA}+\%$ Filler $)$

$$
\begin{aligned}
& =100 \%-(33,79 \%+6,37 \%) \\
& =59,87 \%
\end{aligned}
$$

Nilai Filler adalah agregat halus lolos saringan No. 200. Dari hasil kombinasi diperoleh agregat yang lolos saringan No. 200 sebesar 6,37\%. Maka nilai Filler $=6,37 \%$ Dengan nilai: $\mathrm{CA}=33,79 \%$

$$
\begin{aligned}
& \mathrm{FA}=59,87 \% \\
& \text { Filler }=6,37 \%
\end{aligned}
$$

$\mathrm{Pb}=0,035(\% \mathrm{CA})+0,045(\% \mathrm{FA})+0,18(\%$ Filler $)+$ Konstanta

$\mathrm{Pb}=(0,035 \times 33,79)+(0,045 \times 59,84)+(0,18 \times 6,37)+2,0$ 
$\mathrm{Pb}=7,02 \approx 7 \%$

Perhitungan kadar aspal tengah yang diperoleh mendekati nilai 7,5\%, yang kemudian diurutkan dua variasi kadar aspal ke bawah dan dua variasi kadar aspal ke atas dengan interval 0,5\%. Dari hasil perhitungan perkiraan kadar aspal diperoleh lima variasi kadar aspal yaitu $6 \%, 6,5 \%, 7 \%, 7,5 \%$,dan $8 \%$. Persentase terhadap berat total agregat yang digunakan yaitu 1200 gram.

Perhitungan berat material dan aspal dalam campuran berdasarkan proporsi yang telah ditetapkan adalah sebagai berikut:

\section{Contoh perhitungan}

Kadar Aspal 6\%

- Agregat Kasar (CA) $30 \%=1200 \times 30 \%$

- Abu Batu (FA) $34 \%=1200 \times 34 \%$

- Pasir (SA)

- Aspal

$$
36 \%=1200 \times 36 \%
$$

\section{Berat Total Agregat}

$$
\begin{aligned}
& =360 \text { gram } \\
& =408 \text { gram } \\
& =4 \begin{array}{ll}
432 & \text { gram }
\end{array}
\end{aligned}
$$

$6 \%=\left(\frac{6}{(100-6)}\right) \times 1200=76,6$ gram

Berat Total Campuran + Aspal $=1200$ gram + 76,6 gram = 1276,6 gram

\begin{tabular}{|c|c|c|c|c|c|c|c|c|c|c|c|c|}
\hline \multicolumn{6}{|c|}{ Berat Total Agregat 1200 gram } & \multirow{3}{*}{$\begin{array}{c}\text { Berat } \\
\text { Total } \\
\text { Agregat } \\
\text { Campuran }\end{array}$} & \multicolumn{5}{|c|}{ Variasi Kadar Aspal } & \multirow{4}{*}{$\begin{array}{l}\text { Kode } \\
\text { Sampel }\end{array}$} \\
\hline \multirow{2}{*}{\multicolumn{2}{|c|}{$\begin{array}{l}\text { Agregat } \\
\text { Kasar }\end{array}$}} & \multirow{2}{*}{\multicolumn{2}{|c|}{ Abu Batu }} & \multirow{2}{*}{\multicolumn{2}{|c|}{ Pasir }} & & $6 \%$ & $6,5 \%$ & $7 \%$ & $7,5 \%$ & $8 \%$ & \\
\hline & & & & & & & \multicolumn{5}{|c|}{$\begin{array}{c}\text { Berat Kadar Aspal Terhadap Total } \\
\text { Campuran }\end{array}$} & \\
\hline$\%$ & gram & $\%$ & gram & $\%$ & Gram & gram & \multicolumn{5}{|c|}{ Gram } & \\
\hline 30 & 360 & 34 & 408 & 36 & 432 & 1200 & 76,6 & 83,4 & 90,3 & 97,3 & 104,3 & I \\
\hline
\end{tabular}

Perhitungan rencana berat material dan aspal dapat dilihat pada tabel berikut:

Tabel 5. Rencana Komposisi Campuran

Sumber: Hasil Perhitungan (2020)

Tabel 6. Hasil Pengujian Parameter Karakteristik Marshall

\begin{tabular}{|c|c|c|c|c|c|c|}
\hline \multirow{2}{*}{$\begin{array}{c}\text { Kadar } \\
\text { Aspal }(\%)\end{array}$} & $\begin{array}{c}\text { Stabilitas } \\
(\mathrm{kg})\end{array}$ & $\begin{array}{c}\text { VMA } \\
(\%)\end{array}$ & $\begin{array}{c}\text { VIM } \\
(\%)\end{array}$ & $\begin{array}{c}\text { VFB } \\
(\%)\end{array}$ & $\begin{array}{c}\text { MQ } \\
(\mathrm{kN} / \mathrm{mm})\end{array}$ & \multirow{2}{*}{ Keterangan } \\
\hline 6 & 938.336 & 20.31 & 6,42 & 68,38 & 314.774 & $\begin{array}{c}\text { VIM Tidak } \\
\text { Memenuhi }\end{array}$ \\
\hline 6,5 & 997.599 & 20.93 & 5,84 & 72,11 & 323.974 & $\begin{array}{c}\text { VIM Tidak } \\
\text { Memenuhi }\end{array}$ \\
\hline 7,0 & 1312.183 & 20.97 & 4.53 & 78,51 & 425.664 & Memenuhi \\
\hline 7,5 & 1185.266 & 21.39 & 3.66 & 82,88 & 372.558 & Memenuhi \\
\hline 8,0 & 1200.666 & 21.84 & 2.82 & 87,10 & 387.768 & $\begin{array}{c}\text { VIM Tidak } \\
\text { Memenuhi }\end{array}$ \\
\hline Spesifikasi & $>600$ & $>17$ & $3-5$ & $>68$ & $>250$ & \multicolumn{1}{|c|}{} \\
\hline
\end{tabular}


Hasil dari pengujian Marshall I ini menunjukkan bahwa pada kadar aspal 7,0\%, dan $7,5 \%$, campuran aspal tersebut memenuhi spesifikasi terhadap semua parameter Marshall, sedangkan pada kadar aspal 6,0\%, 6,5\% dan 8,0\% beberapa parameter Marshall pada campuran aspal tersebut tidak memenuhi spesifikasi.

Tabel 7. Rencana Komposisi Campuran dengan Variasi Persentase Abu Batu Kapur Sebagai Bahan Pengganti Filler

\begin{tabular}{|c|c|c|c|c|c|c|c|c|c|c|}
\hline \multirow{2}{*}{\multicolumn{2}{|c|}{$\begin{array}{c}\text { 'Kadar Filler } \\
\text { awal }\end{array}$}} & \multirow{2}{*}{\multicolumn{2}{|c|}{$\begin{array}{c}\text { Berat } \\
\text { Pengganti } \\
\text { Filler (gram) }\end{array}$}} & \multirow{3}{*}{$\begin{array}{c}\text { Berat } \\
\text { Total } \\
\text { Agregat } \\
\text { (gram) }\end{array}$} & \multicolumn{3}{|c|}{ Berat Agregat (gram) } & \multirow{2}{*}{\multicolumn{2}{|c|}{ KAO }} & \multirow{3}{*}{$\begin{array}{c}\text { Berat Total } \\
\text { Campuran } \\
\text { (gram) }\end{array}$} \\
\hline & & & & & \multirow{2}{*}{\begin{tabular}{|c|}
$\begin{array}{c}\text { Agregat } \\
\text { Kasar }\end{array}$ \\
$30 \%$ \\
\end{tabular}} & \multirow{2}{*}{$\begin{array}{l}\text { Abu } \\
\text { Batu } \\
34 \%\end{array}$} & \multirow{2}{*}{$\begin{array}{l}\text { Pasir } \\
36 \%\end{array}$} & & & \\
\hline$\%$ & Gram & $\%$ & Gram & & & & & $\%$ & Gram & \\
\hline 6,37 & 81,64 & 0 & 0 & 1200 & 360 & 408 & 432 & 7,35 & 95,20 & 1295,20 \\
\hline 6,37 & 81,64 & 6 & 5,21 & 1200 & 360 & 408 & 432 & 7,35 & 95,20 & 1295,20 \\
\hline 6,37 & 81,64 & 7 & 6,14 & 1200 & 360 & 408 & 432 & 7,35 & 95,20 & 1295,20 \\
\hline 6,37 & 81,64 & 8 & 7,10 & 1200 & 360 & 408 & 432 & 7,35 & 95,20 & 1295,20 \\
\hline 6,37 & 81,64 & 9 & 8,07 & 1200 & 360 & 408 & 432 & 7,35 & 95,20 & 1295,20 \\
\hline 6,37 & 81,64 & 10 & 9,07 & 1200 & 360 & 408 & 432 & 7,35 & 95,20 & 1295,20 \\
\hline
\end{tabular}

Sumber: Hasil Perhitungan (2021)

Hasil dari pengujian parameter karakteristik Marshall pada percobaan Marshall II pada campuran dengan variasi persentase abu batu kapur sebagai bahan pengganti filler dapat dilihat pada Tabel 8 berikut ini.

Tabel 8. Hasil Pengujian Karakteristik Marshall Filler sebagai bahan pengganti Filler terhadap berat total Agregat

\begin{tabular}{|c|c|c|c|c|c|c|}
\hline \multirow{2}{*}{$\begin{array}{c}\text { Kadar } \\
\text { Pengganti } \\
\text { Filler }(\%)\end{array}$} & \multicolumn{5}{|c|}{ Parameter Karakteristik Marshall } & \multirow[b]{2}{*}{ Keterangan } \\
\hline & $\begin{array}{c}\text { Stabilitas } \\
\quad(\mathrm{kg})\end{array}$ & $\begin{array}{c}\text { VMA } \\
(\%)\end{array}$ & $\begin{array}{l}\text { VIM } \\
(\%)\end{array}$ & $\begin{array}{l}\text { VFB } \\
(\%)\end{array}$ & $\begin{array}{c}\text { MQ } \\
(\mathrm{kN} / \mathrm{mm})\end{array}$ & \\
\hline 0 & 1250,00 & 21,20 & 4,03 & 80,15 & 390,100 & Hasil Marshall I \\
\hline 6 & 1363,056 & 21.62 & 4,36 & 79,84 & 317,268 & Memenuhi \\
\hline 7 & 1363,056 & 21,34 & 4,02 & 81,19 & 318,180 & Memenuhi \\
\hline 8 & 1392,688 & 20,98 & 3,58 & 82,95 & 311,729 & Memenuhi \\
\hline 9 & 1419,133 & 20,29 & 2,74 & 86,52 & 325,292 & $\begin{array}{l}\text { VIM Tidak } \\
\text { Memenuhi }\end{array}$ \\
\hline 10 & 1458,005 & 19,89 & 2,25 & 88,71 & 325,568 & $\begin{array}{l}\text { VIM Tidak } \\
\text { Memenuhi }\end{array}$ \\
\hline Spesifikasi & $>600$ & $>17$ & $3-5$ & $>68$ & $>250$ & \\
\hline
\end{tabular}

Sumber: Hasil Perhitungan (2021)

Dari hasil pengujian Marshall II ini menunjukan bahwa pada bahan pengganti filler dalam campuran pada persentase $6 \%, 7 \%$ dan $8 \%$ terhadap berat total agregat, campuran kadar pengganti filler tersebut sudah memenuhi Spesifikasi Parameter Marshall pada Umum (2018) Revisi 2 (dua). Sedangkan untuk penganti filler persentase $9 \%$ dan $10 \%$, nilai parameter karakteristik Marshall dari rongga dalam campuran (VIM) 
tidak memenuhi Spesifikasi. Nilai rongga dalam campuran (VIM) untuk persentase kadar pengganti filler $9 \%$ dan $10 \%$ yaitu sebesar $2,74 \%$ dan $2,25 \%$, dibawah nilai yang disyaratkan dari Spesifikasi Umum (2018) revisi 2 (dua) yaitu nilai rongga dalam campuran (VIM) sebesar 3\%-5\%.

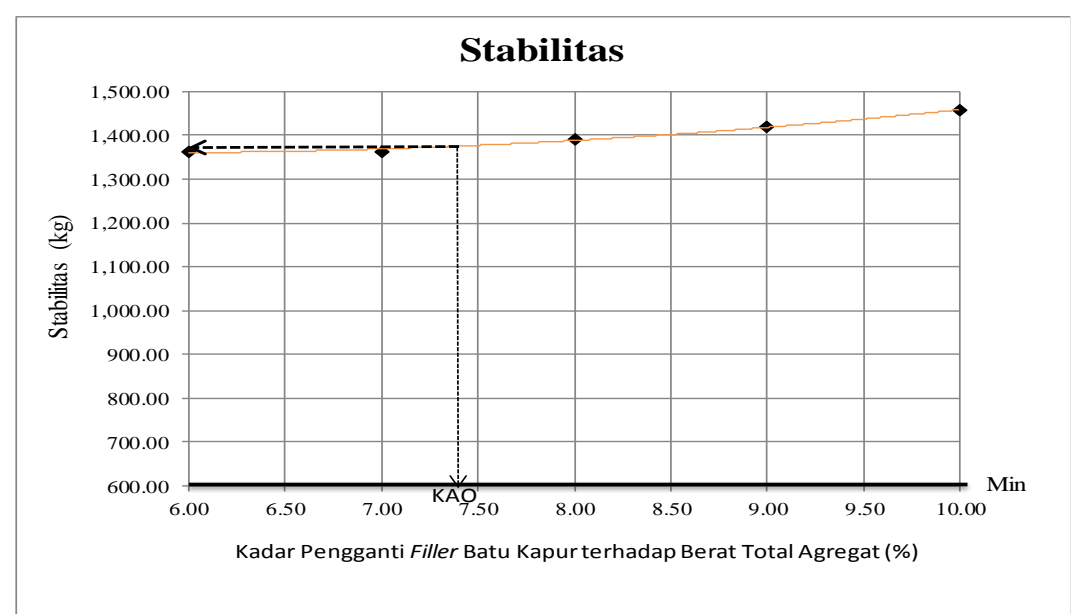

Gambar 3. Grafik Hubungan Stabilitas terhadap

Variasi Kadar Pengganti Filler

Dari grafik di atas dapat dilihat bahwa nilai stabilitas yang diperoleh pada percobaan Marshall II sudah memenuhi spesifikasi yang disyaratkan oleh Spesifikasi Umum (2018) Revisi 2 (dua) yaitu minimal sebesar $600 \mathrm{~kg}$. Semakin besar persentase pengganti kadar filler pada campuran aspal panas, maka nilai stabilitas yang dihasilkan akan semakin besar. Nilai stabilitas tertinggi dicapai pada variasi kadar pengganti filler sebesar 10\% dari berat Agregat total, yaitu sebesar 1458,005 kg.

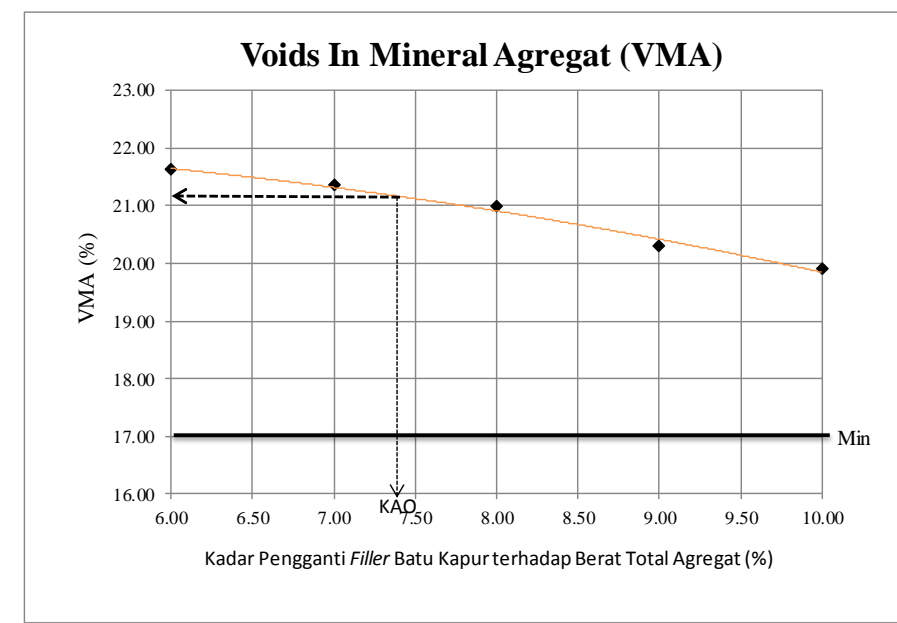

Gambar 4. Grafik Hubungan Rongga Antar Agregat (VMA) Terhadap Variasi Kadar Pengganti Filler

Dari gambar di atas menunjukkan bahwa nilai tertinggi rongga antar agregat (VMA) terjadi pada variasi kadar pengganti filler 6\% yaitu sebesar 21,62\% dan nilai terendah rongga antar agregat (VMA) terjadi pada kadar aspal $10 \%$ yaitu sebesar $19,89 \%$. Nilai rongga antar agregat (VMA) pada variasi kadar pengganti filler berturut-turut memenuhi persyaratan Spesifikasi Bina Marga (2018) revisi 2 (dua) untuk campuran Hot Rolled Sheet Wearing Course (HRS-WC). 
Hubungan Rongga Udara dalam Campuran (Void In Mixture/VIM) terhadap Variasi Pengganti filler abu batu kapur.

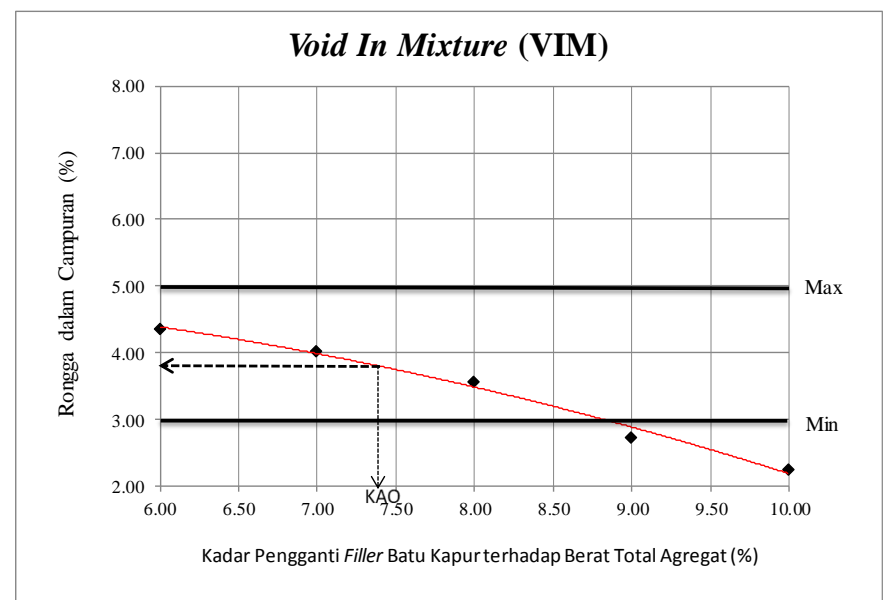

Gambar 5. Grafik Hubungan Rongga Udara dalam Campuran (VIM) terhadap Variasi Kadar Pengganti Filler.

Dari Gambar 5 menunjukan nilai rongga udara dalam campuran (VIM) yang memenuhi spesifikasi yaitu pada variasi bahan pengganti filler dengan persentase $6 \%$, $7 \%$, dan $8 \%$ yang nilainya berturut-turut yaitu 4,36\%, 4,02\%, 3,58\%. Sedangkan untuk variasi bahan pengganti filler presentase sebesar $9 \%$ dan $10 \%$ tidak memenuhi spesifikasi karena berada di luar bentang syarat spesifikasi, yang nilainya yaitu sebesar $2,74 \%$ dan 2,25\%. Dari grafik dapat disimpulkan bahwa semakin besar kadar bahan pengganti filler pada campuran, maka akan menurunkan nilai rongga udara dalam campuran (VIM).

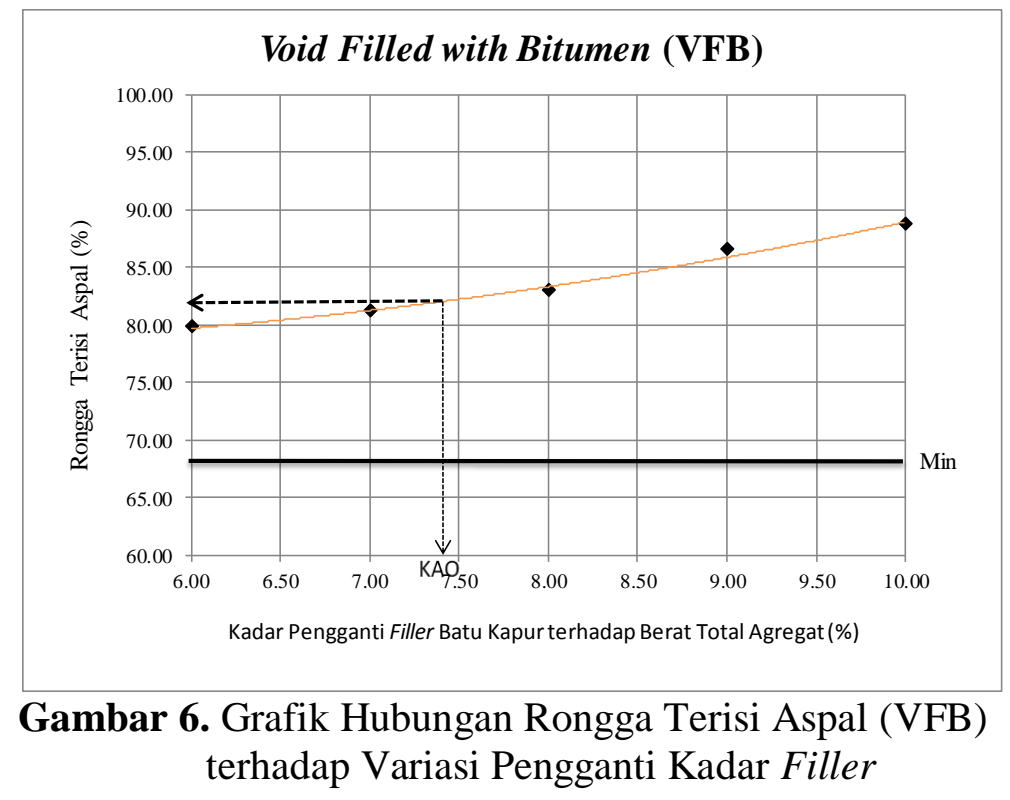

Dari gambar di atas menunjukan bahwa nilai rongga terisi aspal (VFB) pada percobaan Marshall II sudah memenuhi spesifikasi yang ditetapkan oleh Spesifikasi Umum (2018) revisi 2 (dua)yaitu nilainya lebih besar dari $68 \%$. 
JURNAL KACAPURI

JURNAL KEILMUAN TEKNIK SIPIL

Volume 4 Nomor 2 Edisi Desember 2021

Nilai VFB terbesar yaitu pada penganti kadar filler persentase $10 \%$ yaitu besarnya $88,71 \%$. Nilai rongga terisi aspal (VFB) cenderung meningkat seiring dengan besarnya persentase kadar pengganti filler yang diganti ke campuran. Hal tersebut disebabkan karena filler ikut bercampur dengan aspal dan juga mengisi rongga-rongga yang ada pada campuran tersebut.

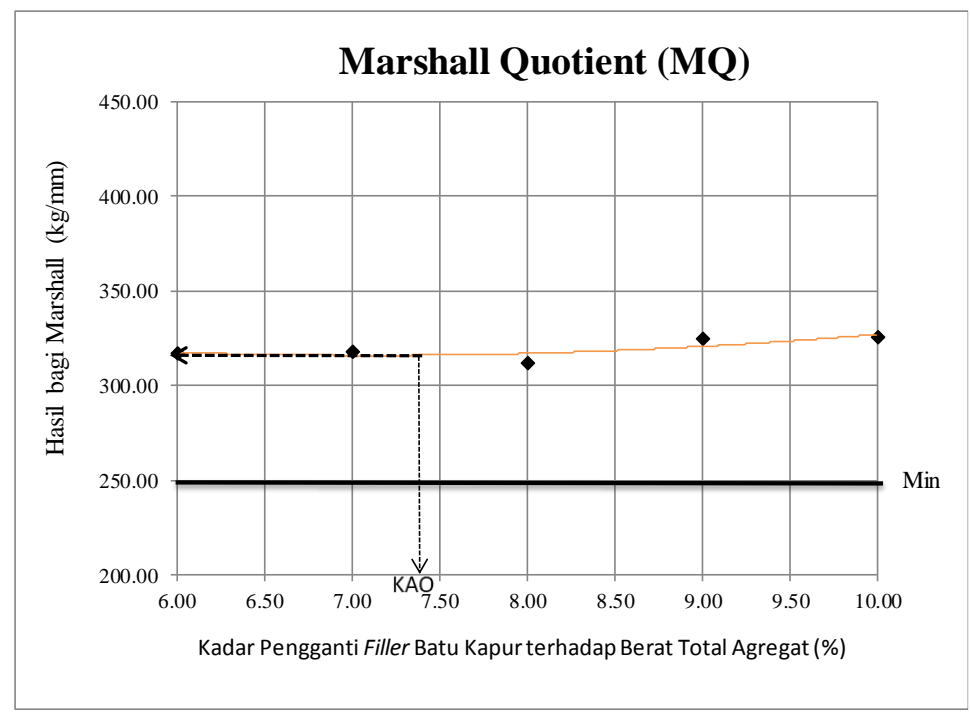

Gambar 7. Grafik Hubungan Nilai Hasil Bagi Marshall terhada Variasi Kadar Pengganti Filler

Gambar di atas menunjukan bahwa nilai hasil bagi Marshall (Marshall Quotient) pada percobaan Marshall II sudah memenuhi spesifikasi yang ditetapkan oleh Spesifikasi Bina Umum (2018) revisi 2 (dua) yaitu nilainya lebih besar dari $250 \mathrm{~kg} / \mathrm{mm}$. Nilai hasil bagi Marshall tertinggi dialami pada variasi kadar pengganti filler sebesar $10 \%$ yaitu nilainya $325,568 \mathrm{~kg} / \mathrm{mm}$.

Dari hasil evaluasi sifat fisik benda uji pada percobaan Marshall II, dapat dilihat rentang kadar pengganti bahan filler yaitu :

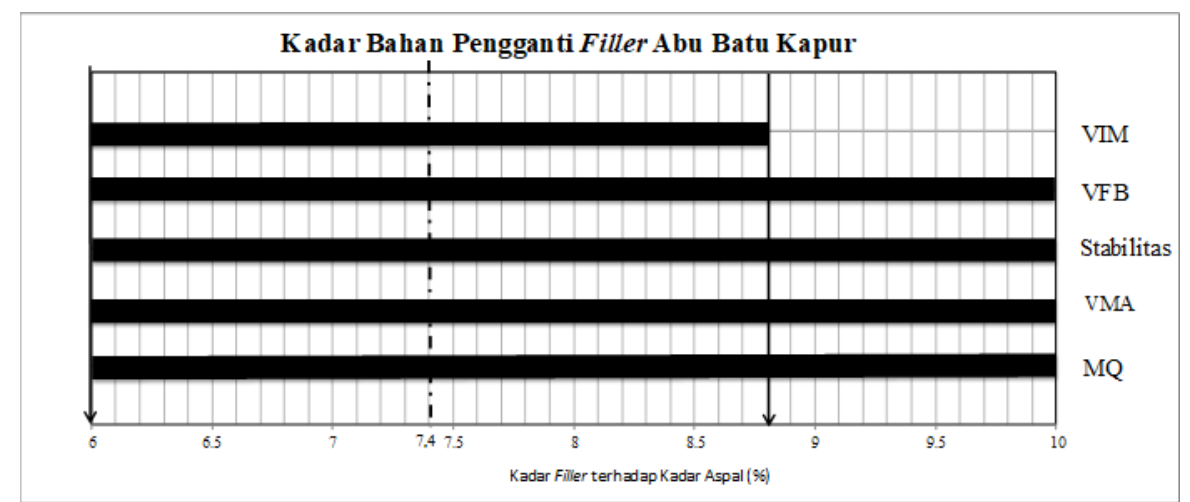

Gambar 8. Grafik Hubungan Nilai Parameter Marshall terhadap Variasi Kadar Pengganti Filler

Hasil evaluasi sifat karakteristik Marshall menunjukan bahwa rentang pengganti kadar filler persentase $6 \%$ hingga $8,8 \%$ campuran memenuhi semua persyaratan yang ditentukan. Berdasarkan rentang tersebut diambil nilai kadar pengganti filler optimum dilihat dari nilai parameter Marshall memenuhi semua persyaratan spesifikasi yang telah ditentukan dan dilihat dari nilai stabilitas tertinggi, yaitu pada kadar pengganti filler 
JURNAL KACAPURI

JURNAL KEILMUAN TEKNIK SIPIL

Volume 4 Nomor 2 Edisi Desember 2021

sebesar 7,40\% sehingga dapat ditetapkan sebagai kadar bahan pengganti filler. Dari hasil pengujian maka didapat hasil nilai parameter Marshall kadar filler optimum yang bernilai $7,40 \%$ dapat dilihat pada Tabel 8.

Tabel 9. Nilai Parameter Marshall pada Kadar Pengganti Filler Optimum

\begin{tabular}{|c|c|c|c|c|}
\hline No. & Karakteristik Marshall & Nilai & Persyaratan & Satuan \\
\hline 1 & Stabilitas & 1385,00 & 600 & $\mathrm{Kg}$ \\
\hline 2 & VMA & 21,15 & $\geq 17$ & $\%$ \\
\hline 3 & VIM & 3,90 & $3-5$ & $\%$ \\
\hline 4 & VFB & 82,00 & $\geq 68$ & $\%$ \\
\hline 5 & Hasil Bagi Marshall & 320,00 & $\geq 250$ & $\mathrm{Kg} / \mathrm{mm}$ \\
\hline
\end{tabular}

Sumber: Hasil Perhitungan (2021)

Dapat dilihat dari tabel di atas bahwa nilai parameter karakteristik Marshall dari Kadar Filler Optimum memiliki stabilitas sebesar 1385,00 kg, VMA sebesar 21,15 mm, rongga dalam campuran (VIM) sebesar 3,90\%, rongga terisi aspal (VFB) sebesar 82,00\% dan hasil bagi Marshall (MQ) sebesar 320,00 kg/mm.

Dari hasil pengujian, maka dapat dilihat perbandingan parameter karakteristik Marshall antara campuran aspal tanpa menggunakan bahan pengganti filler dan yang menggunakan abu batu kapur sebagai bahan pengganti dapat dilihat pada Tabel 9.

Tabel 10. Perbandingan Nilai Parameter Marshall Campuran Tanpa Filler abu batu kapur dan dengan Menggunakan KadarPengganti Filler Abu Batu Kapur Optimum

\begin{tabular}{|c|c|c|c|c|c|c|c|}
\hline \multirow{2}{*}{$\begin{array}{c}\text { Komposisi } \\
\text { Campuran }\end{array}$} & \multicolumn{2}{|c|}{ Kadar } & \multicolumn{5}{|c|}{ Parameter Karakteristik Marshall } \\
\cline { 2 - 8 } & $\begin{array}{c}\text { KAO } \\
(\%)\end{array}$ & $\begin{array}{c}\text { Filler } \\
(\%)\end{array}$ & $\begin{array}{c}\text { Stabilitas } \\
(\mathrm{kg})\end{array}$ & $\begin{array}{c}\text { VMA } \\
(\%)\end{array}$ & $\begin{array}{c}\text { Rongga } \\
\text { dalam } \\
\text { Campuran } \\
(\%)\end{array}$ & $\begin{array}{c}\text { Rongga } \\
\text { Terisi } \\
\text { Aspal }(\%)\end{array}$ & $\begin{array}{c}\text { Hasil Bagi } \\
\text { Marshall } \\
(\mathrm{kg} / \mathrm{mm})\end{array}$ \\
\hline I & 7,35 & 0 & 1250,00 & 21,2 & 4,03 & 80,15 & 390,100 \\
\hline II & 7,35 & 7,40 & 1385,00 & 21,15 & 3,90 & 82,00 & 320,500 \\
\hline Spesifikasi & - & & $>600$ & $>17$ & $3-5$ & $>68$ & $>250$ \\
\hline
\end{tabular}

Sumber: Hasil Perhitungan (2021)

Dari tabel di atas dapat dilihat bahwa kadar pengganti filler optimum dengan abu batu kapur sebesar 7,40\% dari berat total agregat, nilai stabilitas naik 10,8\% dari nilai stabilitas campuran tanpa menggunakan bahan pengganti filler yaitu mengalami kenaikan sebesar $135 \mathrm{~kg}$, nilai VMA turun sebesar $0,5 \%$, rongga dalam campuran turun sebesar $0,13 \%$, rongga terisi aspal naik sebesar $1,85 \%$ dan hasil bagi Marshall turun sebesar 70,1 $\mathrm{kg} / \mathrm{mm}$.

\section{PENUTUP}

\section{Kesimpulan}

Berdasarkan hasil penelitian dan pembahasan yang telah diuraikan sebelumnya, pada "Kajian Karakteristik Marshall Campuran Hot Rolled Sheet Wearing Course (HRS-WC) menggunakan Bahan Pengganti Filler Jenis Abu Batu Kapur" ini disimpulkan beberapa hal sebagai berikut:

1. Agregat penyusun dalam perencanaan campuran Hot Rolled Sheet Wearing Course $(H R S-W C)$ dari hasil pemeriksaan sifat-sifat fisik agregat berupa pemeriksaan 
gradasi (analisa saringan), berat jenis dan penyerapan, dan keausan agregat kasar semuanya memenuhi persyaratan spesifikasi.

2. Komposisi yang dihasilkan dalam perencanaan campuran Hot Rolled Sheet Wearing Course (HRS-WC) terdiri dari 30\% agregat kasar, 34\% abu batu dan 36\% Pasir.

3. Hasil penelitian terhadap Parameter Marshall yang memenuhi spesifikasi terhadap kadar aspal pada campuran komposisi I (tanpa pengganti filler) dengan variasi kadar aspal $6 \%, 6,5 \%, 7 \%, 7,5 \%$ dan $8 \%$. Komposisi II (menggunakan pengganti filler) dengan variasi kadar pengganti filler $6 \%, 7 \%, 8 \%, 9 \%$ dan 10\%, memberikan hasil sebagai berikut:

a. Pada komposisi I kadar aspal yang memenuhi spesifikasi yaitu 6,8\%-7,9\% sehingga diperoleh KAO sebesar 7,35\%.

b. Pada komposisi II kadar aspal yang memenuhi spesifikasi yaitu 6\%-8,8\% sehingga diperoleh kadar pengganti optimum sebesar 7,40\%.

4. Dilihat dari nilai Kadar Aspal Optimum (KAO) didapat nilai parameter Marshall pada masing-masing komposisi, sebagai berikut:

a. Pada komposisi I dengan Kadar Aspal Optimum (KAO) sebesar 7,35\% didapat nilai stabilitas $1250 \mathrm{~kg}$, VMA 21,2\%, rongga dalam campuran (VIM) 4,03\%, rongga terisi aspal (VFB) 80,15\% dan hasil bagi Marshall $390,100 \mathrm{~kg} / \mathrm{mm}$.

b. Pada komposisi II dengan kadar pengganti filler Optimum (KAO) sebesar 7,40\% didapat nilai stabilitas $1385,00 \mathrm{~kg}$, VMA $21,15 \%$ rongga dalam campuran (VIM) $3,90 \%$, rongga terisi aspal (VFB) $82 \%$ dan hasil bagi Marshall 320,500 kg/mm.

5. Pengganti filler optimum dengan abu batu kapur sebesar $7,40 \%$ dari berat total agregat, nilai stabilitas naik $10,8 \%$ dari nilai stabilitas campuran tanpa menggunakan bahan pengganti filler yaitu mengalami kenaikan sebesar $135 \mathrm{~kg}$, nilai VMA turun sebesar $0,5 \%$, rongga dalam campuran turun sebesar $0,13 \%$, rongga terisi aspal naik sebesar $1,85 \%$ dan hasil bagi Marshall turun sebesar $70,1 \mathrm{~kg} / \mathrm{mm}$.

6. Dilihat dari sifat-sifat fisik dan parameter Marshall berupa nilai stabilitas,VMA, rongga terisi aspal (VFB) dan hasil bagi Marshall penggunaan abu batu kapur dapat digunakan sebagai bahan pengganti filler untuk campuran perkerasan Hot Rolled Sheet Wearing Course (HRS-WC), sedangkan untuk nilai rongga dalam campuran (VIM) dengan variasi kadar pengganti filler 9\%-10\% kurang dari persyaratan spesifikasi (min. 3-5\%). Hal ini disebabkan oleh abu batu kapur membuat campuran menjadi lebih rapat gradasinya.

\section{Saran}

Berdasarkan hasil penelitian dan perhitungan karakteristik campuran Hot Rolled Sheet Wearing Course (HRS-WC) dengan menggunakan metode Marshall, adapun saran dari penulis yaitu:

1. Pengontrolan dalam pembuatan dan pemeriksaan benda uji lebih ditingkatkan agar memberikan hasil yang lebih baik.

2. Diharapkan penelitian ini bisa dijadikan alternatif bahan pertimbangan dalam penggunaan bahan pengganti filler pada campuran Hot Rolled Sheet Wearing Course (HRS-WC) di lapangan.

3. Apabila akan dilakukan pekerjaan di lapangan menggunakan abu batu kapur sebagai pengganti filler, jika ingin nilai stabilitas tinggi yang diutamakan maka persentase kadar pengganti filler $9 \%$ sampai $10 \%$, tetapi perkerasan akan mudah retak. Hal ini terjadi karena nilai VIM yang terlalu rendah sedangkan nilai stabilitas tinggi. Baiknya kadar pengganti filler abu batu kapur 6\% sampai 8\% saja agar didapat hasil yang baik. Karena pada kadar pengganti filler abu batu kapur 6\% sampai $8 \%$ sudah 
JURNAL KACAPURI

JURNAL KEILMUAN TEKNIK SIPIL

Volume 4 Nomor 2 Edisi Desember 2021

didapat peningkatan nilai stabilitas lebih tinggi dari pada campuran tanpa pengganti filler, nilai VIM juga meningkat menjadikan campuran seimbang tahanan terhadap beban berat namun tidak mudah retak.

\section{DAFTAR PUSTAKA}

Agung, H. 2016. Penggunaan Abu Batu Kapur Desa Buhut Jaya Kabupaten Kapuas Sebagai Tambahan Filler Pada Campuran Hot Rolled Sheet-Base (HRS-Base). Tugas Akhir. Fakultas Teknik, Universitas Palangka Raya: Palangka Raya.

Azizah, N. 2017. Kinerja Campuran Hot Rolled Sheet-Wearing Course (HRS-WC) Dengan Filler Abu Ampas Tebu. Tugas Akhir. Universitas Negeri Malang : Malang.

Natalia, S. 2019. Analisis Penggunaan Pasir Limbah Tambang Emas Dari Desa Goha dan Desa Bawan Kabupaten Pulang Pisau Sebagai Agregat Pada Campuran Hot Rolled Sand Sheet (HRSS). Tugas Akhir. Fakultas Teknik, Universitas Palangka Raya : Palangka Raya.

Soehartono. 2015. Teknologi Aspal dan Penggunaannya dalam Konstruksi Perkerasan Jalan. Yogyakarta: Andi Offset.

Setiawan, R.M. 2013. Komparasi Penggunaan Filler Kaca Pada Campuran HRS Dan SMA Terhadap Karakteristik Marshall Dan Workabilitas. Skripsi.Fakultas Teknik, Universitas Muhammadiyah Surakarta: Surakarta.

Direktorat Jenderal Bina Marga. 2018). Spesifikasi Umum 2018 (revisi 2). Jakarta: Kementerian Pekerjaan Umum.

Sukirman, S. 2003. Beton Aspal Campuran Panas, Jakarta : Granit.

Yahya, Y. 2018. Analisis Karakteristik Marshall Campuran Hot Rolled Sheet Wearing Course (HRS-WC). Tugas Akhir. Fakultas Teknik, Universitas Palangka Raya : Palangka Raya.

Yacob, M. 2017. Pengaruh Kadar Filler Abu Batu Kapur dan Tempurung Kelapa Terhadap Karakteristik Marshall Pada Campuran Aspal Beton AC-BC. Tugas Akhir. Fakultas Teknik, Universitas Malikussaleh : Aceh. 